\title{
Study of Potential Culinary Products Made from Taro as a Culinary Attraction Towards the Motivation of Tourists in Bogor
}

\author{
Yustisia Pasfatima Mbulu, I Made Adhi Gunadi \\ Faculty of Tourism \\ Universitas Pancasila Srengseng Sawah \\ Jakarta, Indonesia \\ yustisiapm@gmail.com
}

\begin{abstract}
The tourist attraction is a main mobilization that motivates tourists to visit a certain tourism destination. One of the current progressive tourist attractions is culinary tourism. This culinary tourism is also called gastronomic tourism in which tourists satisfy themselves with various meals from the tourism destination. It is not just about to make their stomach full, but it is also to gain a certain eating experience and learn to cook special foods.Taro has been used as a main ingredient of making taro layered cake in Bogor. Thus, this cake is a culinary tourist attraction in the city. However, taro-based culinary products haven't become the main culinary tourist attraction in Bogor. Therefore, this research is aimed to observe the motivation of tourists who visit Bogor for culinary purpose. The goals of this research are to identify the taro based culinary products as a culinary tourist attraction in Bogor and analyze the relationship between taro-based culinary products and the visitors' motivation. The method used in this research is correlational descriptive method with quantitative approach. The result of this research shows that the taro based culinary products can be culinary tourist attraction in Bogor since they could meet the conditions of food qualities which cope color, appearance, portion, shape, temperature, texture, aroma, level of doneness, and taste. The connection between taro based culinary products with the tourists' motivation can be seen from the result of Pearson correlation in which each dimension of tourists' motivations has a negative correlation. Therefore, there must be improvements so that the level of tourist's motivation for taro based culinary products in Bogor would increase.
\end{abstract}

Keywords- Culinary tourism, Taro based culinary products, Tourist's motivation

\section{INTRODUCTION}

Tourism activities in any region should be incomplete without a tourist attraction. Tourist attraction is a main focus that mobilizes tourism in one region. Tourist attraction is the main mobilisator that motivates tourists to visit a certain area. (Ismayanti, 2010). One of the current progressive tourist attractions is culinary tourism. This culinary tourism is also called gastronomic tourism in which tourists satisfy themselves with various meals from the tourism destination. It is not just about to make their stomach full, but it is also to gain a certain eating experience and learn to cook special foods (Ismayanti, 2010).

Culinary tourist attractionis quite popular and has become a lifestyle in having a holiday in a certain area (Hamdani, 2010). Culinary tourist attraction should offer local gastronomic experiences that have special tastes. Ingredients, appearance, and tastiness that satisfy tourists would be advantages of local culinary products to be accepted by tourists generally (Parma, 2012).

The current trend of tourists is to find specific foods in their destination. Thus, it can be a big opportunity for the destination. Tourists won't hesitate to pay costly foods to enjoy the taste. People's lifestyle has changed also. They don't eat to satisfy their stomach only. They also look for a cozy situation and prime service as parts of the foods they order. Many tourists spare their time to find specific foods and drinks in their destination during their holiday (Adi, 2012).

A survey about the behavior of tourists shows that around $36 \%$ tourists in the region of Asia Pacific decide their destination mainly based on the foods and drinks. The survey also shows that $33 \%$ of local tourists in Indonesia admitted that food would be an essential factor in determining their tourism destination (Asdihiana, 2014).

Furthermore, $86 \%$ of respondents considered tasting famous local specific foods should be very important. $90 \%$ of those respondents want to gain a unique culinary experience when they visit a certain area. $49 \%$ respondents agree that various culinary products should be the most important factor followed by the uniqueness of the foods, choices of specific foods and experiencing culinary tourism attractions such as attending snacks market or foods festival (Asdihiana, 2014).

A city that becomes a culinary tourist attraction is Bogor. Bogor is one of perfect destinations to fulfill tourist's appetite and buy foods. Bogor is situated in West Java province. The width is 118,50 square kilometres and the population is around 949,006. Bogor also has the nickname Rain city. It is because the climate is very rainy compared with other areas in Indonesia. With the characteristic of Bogor which is very rainy, 
the Dutch East Indies government used this city as a center of all botanical researches in the era. Since its location is close to the capital city, Bogor has become a weekend destination of tourists. Apart from the significant amount of natural resources, Bogor is also known for its culinary tourism attractions (www.tempatwisataid.com).

The specialty of Bogor is a kind of taro called Talas Bogor. People usually sell the raw taros in a package which consists of some taros. People usually fry it, boil it or steam it. They also make taro chips, taro in sweet coconut milk and so on. However, many people use taro as the main ingredient to make cakes nowadays. Taro is also used to create $\mathrm{pH}$ balance in our body. The nutrition in Taro itself could cure eczema, asthma, indigestion problem and bronchitis (wisata.kompasiana.com, 2013).

Formerly, taro was used to cook side dishes only. Now, people could have various foods made of taro with a tempting taste. There are taro cake, taro brownies and taro rainbow cake. The pioneer of taro layer cake was a company named PT. Agrinesi Raya in 2011. Their main product is called "Lapis Bogor Sangkuriang" layer cake with several variants such as original cheese, original blueberry, original tiramisu, original chocolate, original cappuccino, full taro cheese, full taro blueberry, full taro tiramisu, full taro brown, full taro cappuccino, the green cheese, green tea chocolate, durian cheese, durian chocolate, cheese brownies, strawberry cheese and cocopandan. The process doesn't take any preservative and taro cakes could only survive up to four days and seven days in the refrigerator. Thus, it is safe for taro cakes to be delivered out of the city as souvenirs. The soft texture, special taste and aroma, beautiful packaging and shape become special points to select this layer cake as the souvenir from Bogor.

By looking at the development of culinary products made of taro, taro layer cake can be used as a culinary tourist attraction in Bogor. However, taro-based culinary products haven't become the major tourist attraction yet because there is a wide range of culinary products such as mini breads called roti unyil, apple pie, baked macaroni and so on. Thus, this study wants to identify the taro-based culinary products as the main culinary tourist attraction in Bogor and to analyze the connection of taro-based culinary products with the motivation of tourists visiting Bogor (See Figure 1.1 Conceptual Framework)

\section{CONCEPTUAL FRAMEWORK}

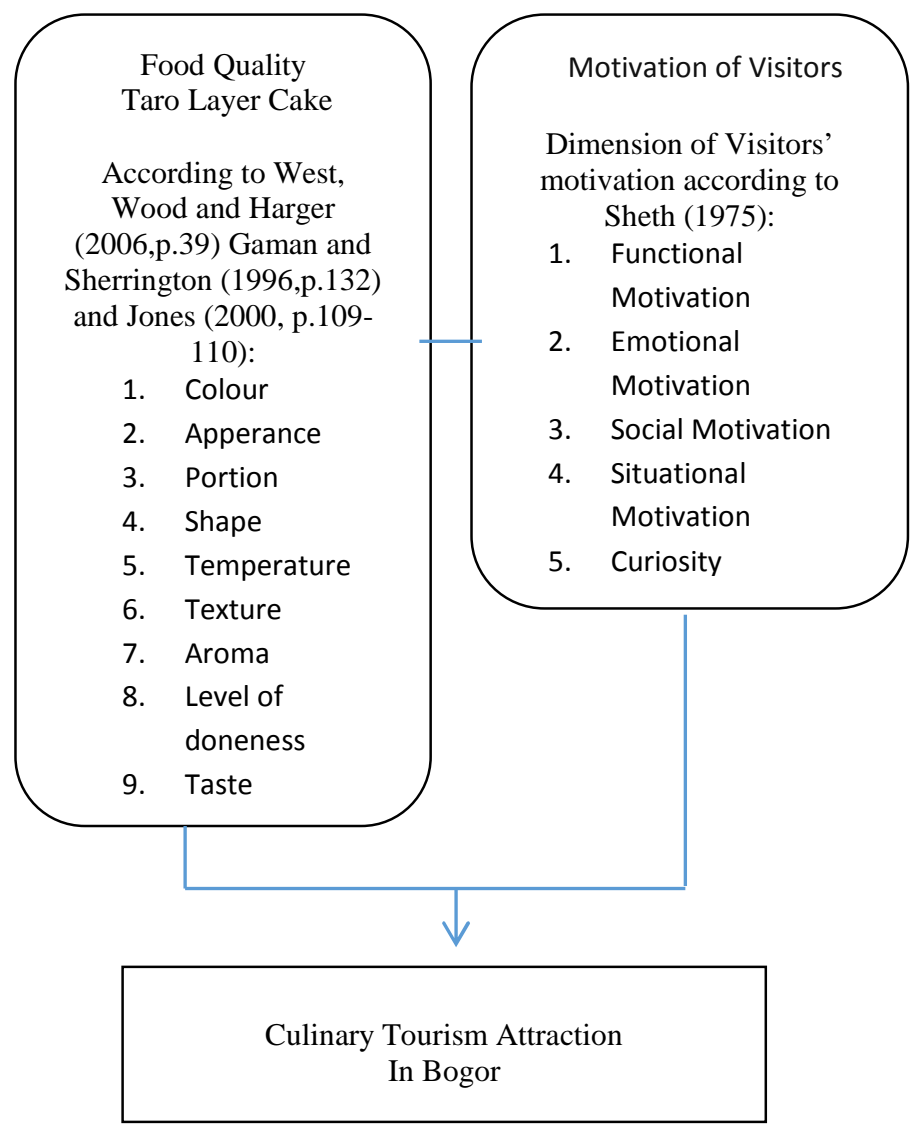

Fig. 1. Conceptual Framework

\section{METHODS}

\section{A. Research Methodology}

The method used in this research is called correlational descriptive with quantitative approach. It describes the connection between taro-based culinary products with the motivation of tourists who visit Bogor. According to Nana Sudjana and Ibrahim (2007:64), descriptive research tries to describe a symptom, an event and an affair that happens in the present. This research is used to examine the hypothesis that will be set.

According to Sugiyono (2008:14), Quantitative research method can be interpreted as a method of research which is based on the philosophy of positivism. It is used to examine the population or a particular sample. The sampling technique is generally done at random. Data collection uses research instruments. The data is quantitative data or statistical in order to test the hypothesis that has been established.

Nan Sudjana and Ibrahim (2007:77) explained about the notion of correlational research method which is the correlation study that studies the connection between two variables or more. The study explains the extension of one variable related to the variants of other variables. 


\section{B. Research Variable}

This research discusses the two variables called independent variable and dependent variable. Independent variable is a variable that has an influence and causes the existence of a dependent variable. Dependent variable is a variable influenced by an independent variable. In this research, the independent variable (x) is the taro-based culinary product while the dependent variable $(\mathrm{y})$ is the motivation of tourists who visit Bogor.

\section{Research Design}

This research consists of two variables which are Independent Variable (x) showed by taro-based culinary products and Dependent Variable (y) showed by the motivation of tourists in Bogor. The goal of this research is to identify taro-based culinary products as a culinary tourist attraction in Bogor and analyze the connection between taro-based culinary products and the visitors' motivation in Bogor. According to West, wood and Harger (2006, p.39), Gaman dan Sherrington (1996, p.132) and Jones (200, p.109-110), the factors that affect a food quality are as follows:

\section{a) Color}

All colors of ingredients must be combined nicely so that the result won't be pale or even mismatched. The combination of colors should help customers raise their appetite.

\section{b) Appearance}

There is a motto saying 'looks good enough to eat'. It is not overwhelming. Any food should appear good. It is essential. Freshness and cleanliness of the served food should be matters that affect the appearance. .

\section{c) Portion}

In serving any food, standard portion should be set. The standard portion is a quantity of item served based on the order. Management is urged to set a clear standard portion size. There must be guidance of how many grams of meat to be served in any portion for example.

\section{d) Shape}

A shape of the food plays an important role to attract people's eyes. An interesting shape of food can be gained by variants of cutting technique. Carrots can be sliced in the shape of dice and lettuce can be sliced in the shape of chiffonade.

\section{e) Temperature}

Customers prefer variants of temperature of any food. It also affects the taste. A sweet taste in a food would be better when the food is still warm while a hot soup should be little bit tasteless.

\section{f) Texture}

There are many textures of food. There are soft food, liquid food, solid food, dry food and moist food. The thinness or thickness of food can be tasted by the pressure and movement of the receptor inside our mouth.

\section{g) Aroma}

Aroma is a food reaction that affects customers in enjoying the food. Customers can smell the food.

\section{h) The level of doneness}

The level of doneness should affect the texture of a food. A well-done carrot should be softer than a half-done carrot. For a certain food such as steak, every people have their own choice as well.

\section{i) Taste}

Our tongue can detect the basic tastes such as sweet, sour, salty and bitter. In a certain food, these four flavours can be united into a unique and interesting taste.

The five dimensions of Visitors' motivation are as followrs (Sheth, 1975):

\section{1) Functional Motivation}

Motivation functional relates to the technique of a product's appearance.

\section{2) Aesthetics - Emotional Motivation}

Aesthetics - emotional motivation involves style, design and comfort of a product. This kind of motivation is essential for brand specification and general product selection. The class of a product is evaluated based on fundamental values embraced by customers in the area of fear, social concern, appreciation towards life quality, appreciation towards art, religious belief and other emotions. Thus, there could be a statement saying that each person intends to choose a product which is suitable with their lifestyle and allows them to express their basic values.

\section{3) Social Motivation}

Social motivation should relate to the impacts of relevant consumption towards people's opinions. Status, prestige and price can be reduced. Some products could be chosen as choices based on people's opinions with aesthetics motive.

\section{4) Situational Motivation}

Situational Motivation doesn't mean to be applied in a long term for a specific purpose. Product selection can be influenced by some situational determinants such as availability, discount and accessibility. Situational determinants usually apply for specific brand or type. Selected brand is usually set without any careful evaluation based on the class of product.

\section{5) Curiosity Motivation}

Curiosity Motivation is a motive that should encourage the making of a new product or an innovative product. Customers may taste a new product but the possibility of buying the same product again could be unpredicted. 
TABLE I. THE RELATION AMONG VARIABLES

\begin{tabular}{lccccc}
\hline $\mathbf{Y}$ & \multicolumn{5}{c}{ Visitors' Motivation } \\
\cline { 2 - 6 } & $\begin{array}{c}\text { Functional } \\
(\mathbf{y} 1)\end{array}$ & $\begin{array}{c}\text { Emotional } \\
(\mathbf{y} 2)\end{array}$ & $\begin{array}{c}\text { Social } \\
(\mathbf{y 3})\end{array}$ & $\begin{array}{c}\text { Situational } \\
(\mathbf{y} 4)\end{array}$ & $\begin{array}{c}\text { Curiosity } \\
(\mathbf{y 5})\end{array}$ \\
\hline $\begin{array}{l}\text { Taro- } \\
\text { based } \\
\begin{array}{c}\text { Culinary } \\
\text { products }\end{array}\end{array}$ & $\mathrm{Xy1}$ & $\mathrm{Xy} 2$ & $\mathrm{Xy3}$ & $\mathrm{Xy} 4$ & $\mathrm{Xy5}$ \\
\hline
\end{tabular}

\section{Data Collection Method}

In this research, the primary data is based on a field survey in some culinary tourist attractions in Bogor and the tourists while the secondary data is gained from the internet, books and other resources. The primary data collection was taken directly from respondents through questionnaires and interviewing visitors who chose Taro layer cake in Bogor. The primary data gathered is about the characteristic of the respondents. The secondary data was gained from various resources such as internet and books.

\section{E. The technique of determining respondents.}

There were 100 respondents for this research. They visited Bogor for taro layer cake. The sampling technique was random sampling in which all respondents got a same opportunity to choose one sample (Sugiyono, 2003).

\section{F. Measurement of each variable}

To measure each variable in this research, the technique used is called Likert Scale Measuring Technique. It is used to measure attitude, opinion and perception of someone or a group of people towards social phenomenas (Sugiyono, 2012). All answers of each research instrument used Likert Scale show gradations from positive to negative which can be explained as follows:

TABLE II. LIKERT SCALE

\begin{tabular}{lllll}
\hline $\begin{array}{c}\text { Strongly } \\
\text { Disagree }\end{array}$ & Disagree & Neutral & Agree & $\begin{array}{c}\text { Strongly } \\
\text { Agree }\end{array}$ \\
\hline 1 & 2 & 3 & 4 & 5 \\
\hline
\end{tabular}

Fig. 2. Data analysis technique

After researchers finished the field research and collected data, they analyzed the data. According to Patton in Iqbal Hasan (2010: 29), data analysis is a process of arranging data and organizing it in a pattern, category and basic description unit. The collected data is a raw data because it is still a descriptive unit that involves knowledge, experience, opinion and other things relating to the subject. After being analyzed, the data becomes meaningful. The purpose of data analysis is simplifying collected data so that it can be presented in a systematical order, managed and interpreted correctly.

The data analysis technique is directed into hypothesis test and problem solving. This research applies correlation analysis and regression analysis. The correlation coefficient test is aimed to determine how strong the relation is between two variables.

\section{Correlation Analysis}

Correlation test is aimed to determine a relation between two measurements or two variables. It is to find out the level of relation between variable $X$ (taro-based culinary products) and Variable Y (the motivation of tourists who visit Bogor). In this research, researchers used Pearson product moment correlation technique. The reason is that the interval data was gained from instruments, which applied Likert Scale. It is just in accordance with the statement of Ronny Kountur (2009: 210). He said that data with interval scale or ratio could apply Pearson product moment correlation. The same statement was also given by Iqbal Hasan (2010: 61). He said that the Pearson correlation coefficient formula ( $r$ ) could be used in a simple correlation analysis for an interval variable or ratio with interval variable or ratio.

The formula is as follow:

To ease the interpretation of a relation strength of two variables, the writer set these criterias below (Sarwono: 2006):

$$
\begin{array}{ll}
>0-0,25 & =\text { The correlation is very weak } \\
>0,25-0,5 & =\text { The correlation is strong enough } \\
>0,5-0,75 & =\text { The correlation is strong } \\
>0,75-0,99 & =\text { The correlation is very strong } \\
1 & =\text { The correlation is perfect }
\end{array}
$$

\section{RESULTS AND DISCUSSION}

The Potential Taro-Based Culinary Products as Culinary Tourism Attraction

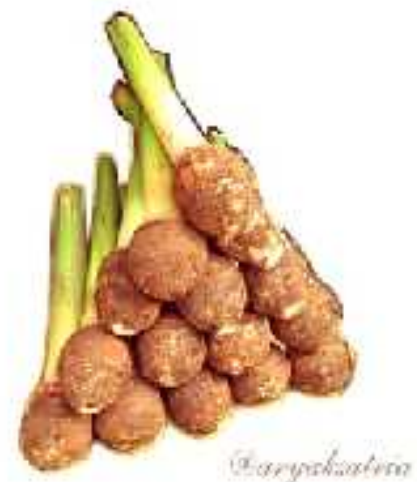

Fig. 3. Taro in Bogor

\section{Resource: aryawardhana.wordpress.com}

Taro originally came from south East Asia before it spread throughout China in the first century, Japan and other regions in Pacific Ocean because of the migration. In Indonesia, there are variants of taro. One of them is called Colocasia Esculena $L$ or Talas Bogor. The variants of taro are showed by the leaves, colors of midrib, shape, taste and the crystal content. Talas Bogor itself consists of crystals that may cause itchiness 
on skin. Thus, the process must be right so that the crystals won't cause itchiness in our throat. In Bogor itself, this kind of taro has become a main commodity for the people. People of medium community cultivate this plant so that they can sell in markets and make some foods for breakfast or snack time. (akardanumbi.blogspot.com).

Nowadays, talas bogor has become a main ingredient of culinary products. Bogor taro flour is an ingredient of taro layer cake. The pioneer was a company called PT. Agrinesi Raya in 2011. Their main product is taro layer cake named "Lapis Bogor Sangkuriang". This cake has several variants such as original cheese, original blueberry, original Tiramisu, original chocolate, original cappuccino, full cheese taro, full blueberry taro, full tiramisu taro, full chocolate taro, full cappuccino taro, cheese with green tea, chocolate with green tea, cheese durian, chocolate durian, cheese brownies, cheese strawberry and coco pandan.

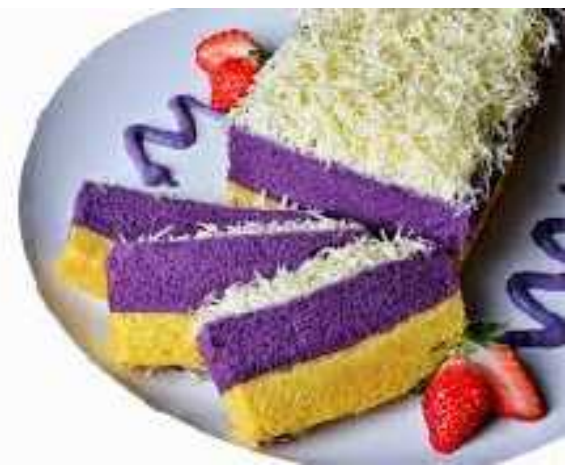

Fig. 4. Bogor Taro Layer Cake

\section{Resource: berbagairesep.com}

According to west, wood and Harger (2006, p.39), Gaman and Sherrington (1996,p.132) and Jones (200,p.109-110), factors affecting food quality are as follows:

\section{A. Color}

The layer cake has various colors such as purple with yellow for cheese original taro layer cake and green with yellow for cheese green tea taro layer cake. These colors can show that Bogor taro layer cake has an interesting specification that may attract tourists and raise their appetite. According to West, Wood and Harger (2006, p.39), Gaman and Sherrington (1996,p.132) and Jones (200,p.109-110), colors of food ingredients must be combined nicely so that the food won't look pale or mismatched. The color combination will be very helpful to raise people's appetite. The food quality in most Bogor taro layer cakes is suitable with the theory set by West, Wood and Harger (2006, p.39), Gaman and Sherrington (1996,p.132) and Jones (200,p.109-110). The colors of Bogor Taro Layer Cake can raise tourists' appetite because of the variants. The specific color of Bogor Taro Layer Cake is purple. This purple color is not caused by food coloring agent but the taro itself.

\section{B. Appearance}

The appearance of Bogor taro layer cake is very interesting. As soon as the cake is served on a plate, its appearance may raise our appetite because there are two layers of the cake with various toppings. One of the toppings is cheese. According to West, Wood and Harger (2006, p.39), Gaman and Sherrington (1996,p.132) and Jones (200,p.109-110), the appearance of a food should be good. That's why a motto saying 'looks good enough to eat' is not overwhelming. Food must look good on a plate as it is an essential factor. The freshness and cleanliness of a served food is an essential example that may affect the food's appearance. The food quality of Bogor taro layer cake is suitable with the theory set by West, Wood and Harger (2006, p.39), Gaman and Sherrington (1996,p.132) and Jones (200,p.109-110). Its appearance is good enough to eat when tourists want to eat it.

\section{Portion}

Bogor taro layer cake has a suitable portion. It is soft and delicious. It is worth to be a culinary souvenir for tourists who visit Bogor. According to West, Wood and Harger (2006, p.39), Gaman and Sherrington (1996,p.132) and Jones (200,p.109-110), standard portion size must be set in serving any food. Standard portion size is described as a quantity of item served every time people order it. Management is urged to set a clear standard portion size secara jelas. It must be clear about how many grams of meat to be served in a portion of food for example. The food quality of Bogor taro layer cake is suitable with the theory set by West, Wood and Harger (2006, p.39), Gaman and Sherrington (1996,p.132) and Jones (200,p.109-110). Bogor taro layer cake shows the standard portion on each package. People could read the ingredients such as egg, taro flour, sugar, butter, milk, cheese and so on. Thus, tourists may know the standard portion clearly.

\section{Shape}

The shape of Bogor taro layer cake is square and it is different from other cakes generally. This square shape shows the layers of the cake so it becomes a special attraction for the tourists to buy and enjoy it. According to West, Wood and Harger (2006, p.39), Gaman and Sherrington (1996,p.132) and Jones (200,p.109-110), shape of a food has an important role to attract people's eyes. An interesting shape of food can be gained by various cutting technique. A carrot can be sliced into the shape of dice. Lettuce can be sliced into the shape of chiffonade. The food quality based on Bogor taro layer cake's shape is suitable with the theory set by West, Wood and Harger (2006, p.39), Gaman and Sherrington (1996,p.132) and Jones (200,p.109-110). Its square shape has an important role in appearing the interesting cake's colors and toppings as the decoration of the cake. Thus, the cake attracts the tourists to buy and eat it.

\section{E. Temperature}

Temperature of Bogor taro layer cake is usually cold or based on room temperature so that tourists may eat it directly. West, Wood and Harger (2006, p.39), Gaman and Sherrington (1996,p.132) and Jones (200,p.109-110) stated that customers would prefer variants of temperature in some food. 
Temperature may also affect its taste. Sweet taste of a food would be better while it is served warm while a hot soup could be little bit tasteless. The food quality based on Bogor taro layer cake's temperature is suitable with the theory set by West, Wood and Harger (2006, p.39), Gaman and Sherrington (1996,p.132) and Jones (200,p.109-110). Tourists can enjoy the cake in cold temperature or room temperature every time and everywhere. The temperature may help tourists taste the delicious cake.

\section{F. Texture}

Bogor taro layer cake has a soft texture so that it can be consumed by children, teenagers, adults and elders. Thus, every tourist can buy and enjoy the cake. According to West, Wood and Harger (2006, p.39), Gaman and Sherrington (1996,p.132) and Jones (200,p.109-110), there are plenty food textures such as soft, solid, dry or moist. The thinness or thickness of food and its shape can be determined by the receptor inside our mouth. The food quality based on Bogor taro layer cake's texture is suitable with the theory set by West, Wood and Harger (2006, p.39), Gaman and Sherrington (1996,p.132) and Jones (200,p.109-110). Tourists can enjoy it because of its soft texture.

\section{G. Aroma}

Bogor taro layer cake has a specific aroma and it is delicious. For example, the original cheese has a good aroma and the cheese may raise people's appetite. According to West, Wood and Harger (2006, p.39), Gaman and Sherrington (1996,p.132) and Jones (200,p.109-110), aroma is a food reaction that may affect customers before they try it. Customers can smell it. The food quality based on bogor taro layer cake's aroma is suitable with the theory set by West, Wood and Harger (2006, p.39), Gaman and Sherrington (1996,p.132) and Jones (200,p.109-110). The cake's aroma is delicious and it can attract tourists to buy and eat it.

\section{H. The level of doneness}

The level of doneness of Bogor taro layer cake is good enough. Thus, its texture and color look interesting and delicious to enjoy. According to West, Wood and Harger (2006, p.39), Gaman and Sherrington (1996,p.132) and Jones (200,p.109-110), the level of doneness will affect the texture of food. For example, well-done carrot will be softer than halfdone carrot. For specific food such as steak, each person has their own choice too. The food Quality based on bogor taro layer cake's level of doneness is suitable with the theory set by West, Wood and Harger (2006, p.39), Gaman and Sherrington (1996,p.132) and Jones (200,p.109-110). The level of doneness of Bogor taro layer cake affects its texture, aroma and shape so that the cake is worthy to sell to tourists who visit Bogor.

\section{Taste}

Bogor taro layer cake is delicious, soft, moist and not too sweet. The flavour of taro is strong in an original taro layer cake while the cheese increases its taste. Other variants are Original cheese, Taro Brownies, Full Taro, Green Tea, Durian Taro and original taro layer cake with various toppings such as blueberry, strawberry, tiramisu, cappuccino and chocolate.
According to West, Wood and Harger (2006, p.39), Gaman and Sherrington (1996,p.132) and Jones (200,p.109-110), the point of tasting on our tongue can detect the basic flavors such as sweet, sour, salty and bitter. In a certain food, these four flavours can be united into a unique and interesting flavor to enjoy. The food quality based on Bogor taro layer cake's taste is suitable with the theory set by West, Wood and Harger (2006, p.39), Gaman and Sherrington (1996,p.132) and Jones (200,p.109-110). The taste of Bogor layer cake is unique and able to attract tourists to buy and enjoy.

The Connection Between Taro-Based Culinary Products and The Visitors' Motivation

Based on the Pearson Correlation in determining the visitors' motivation towards the quality of Bogor taro layer cake, there are some points showed as follows:

\section{A. Color}

1) The food quality based on the cake's color has a negative correlation $-0.200^{*}$ towards the visitors' motivation to buy as a culinary souvenir. It means that if the food quality based on the color increases, visitors's motivation to buy may decrease and vice versa. Visitors's motivation is not caused by the specific culinary souvenir in Bogor but the interesting colors such as purple and yellow in the original taro layer cake with cheese. They are interested to buy it because of its colors.

2) The food quality based on the cake's color has a strong correlation $0.504 * *$ towards the visitors' motivation to buy it because of its interesting design. It means if the food quality based ont its color increases, the visitors' motivation to buy may increase because of the design and vice versa. Thus, two colors design of the cake that shows purple and yellow in the original taro layer cake with cheese could attract tourists to come.

3) The food quality based on the cake's color has a sufficient correlation $0.363 * *$ towards the visitors' motivation to buy the cake because of the brand. It means that the food quality based on the color increases, the visitors's motivation to buy the cake because of the brand may increase and vice versa. The brand used in the layer cake is based on the taro pasta which is safe for human's body so that people can eat it. This fact could motivate tourists to come.

4) The food quality based on the olor has a very weak correlation 0.078 towards the visitors' motivation to buy the cake because of a promotion of discount. It means that if the food quality based on the cake's color increases, visitors' motivation to buy it may increase because of the promotion or discount and vice versa. Puple and yellow in the original taro layer cake with cheese have been able to attract tourists to come. Thus, promotion or discount is not required.

5) The food quality based on the cake's color has a negative correlation -0.159 towards the visitors' motivation to buy the cake because of their curiosity. It means that if the food quality based on the cake's color 
increases, the visitors' motivation to buy it may decrease and vice versa. The visitors' motivation to buy the cake is not based on their curiosity but the specific two colors of the cake. Purple and yellow in the original taro layer cake with cheese could attract tourists to buy the cake.

\section{B. Appearance}

1) The food quality based on the cake's appearance has a negative correlation -0.211 * towards the visitors' motivation to buy the cake. It means that if the food quality based on its appearance increases, the visitors' motivation to buy the cake may decrease and vice versa. Visitors' motivation to buy taro layer cake is not caused by its status as a culinary souvenir from Bogor but the appearance of the cake with cheese toppings. It can attract people and raise people's appetite to eat it.

2) The food quality based on the cake's appearance has a strong correlation $0.568 * *$ towards the visitors's motivation to buy the cake because of the interesting design. It means that if the food quality based on its appearance increases, the visitors's motivation to buy the cake may increase too because of the cake's design and vice versa. Thus, the design of the variants such as original cheese, taro brownies, full taro, green tea, taro durian and original taro layer cake with toppings such as bluebeery, strawberry, tiramisu, cappuccino and chocolate can raise people's appetite and motivate tourists to come.

3) The food quality based on the cake's appearance has a sufficient correlation $0.447 * *$ towards the visitors' motivation to buy the cake. It means that if the food quality based on the cake's appearance increases, the visitors' motivation to buy the cake may increase too because of the brand and vice versa. The appearance of Bogor Taro Layer Cake with a taro-based brand could motivate tourists to come.

4) The food quality based on the cake's appearance has a very weak correlation 0.064 towards the visitors' motivation to buy the cake because of promotion of discount. It means that if the food quality based on the cake's appearance increases, the visitors' motivation to buy the cake because of the promotion or discount may increase as well and vice versa. The attractive appearance of Bogor taro layer cake could raise people's appetite and encourage tourists to buyt it. Thus, promotion or discount is not required.

5) The food quality based on the cake's appearance has a negative correlation $-0.220 *$ towards the visitors' motivation to buy the cake because of their curiosity to try. It means that if the food quality based on the cake's appearance increases, the visitors' motivation to buy it because of their curiosity may decrease and vice versa. The visitors' motivation to buy the cake is not caused by their curiosity to buy but the appearance of the cake itself. It is enough to raise people's appetite and attract tourists to buy.

\section{Portion}

1) The food quality based on the cake's portion has a negative correlation -0.018 towards the visitors' motivation to buy the cake as a culinary souvenir from Bogor. It means that if the food quality based on the cake's portion increases, the visitors' motivation to buy it may decrease and vice versa. Visitors' motivation to buy the cake is not caused by its status as a culinary souvenier from Bogor but the cake's portion is suitable enough. It is neither too big nor too small so that tourists are attracted to buy it.

2) The food quality based on the cake's portion has a sufficient correlation $0.334 * *$ towards the visitors' motivation to buy the cake because of its interesting design. It means that if the food quality based on the cake's portion increases, the visitors' motivation to buy it because of its design may increase too and vice versa. The design of portion appeared on a package of Bogor taro layer cake could motivate tourists to come.

3) The food quality of the cake's portion has a sufficient correlation $0.282 * *$ towards the visitors' motivation to buy the cake because of its brand. It means that if the food quality based on the cake's portion increases, the visitors's motivation to buy it because of the brand may increase as well and vice versa. The portion of Bogor taro layer cake that uses a brand of taro flour could motivate tourists to come.

4) The food quality based on the cake's portion has a very weak correlation 0.052 towards the visitors' motivation to buy the cake because of a promotion or discount. It means that if the food quality based on the cake's portion increases, the visitors' motivation to buy the cake because of the promotion or discount may increase as well and vice versa. The portion of Bogor taro layer cake is suitable enough for tourists. Thus, any promotion or discount is not required to motivate them to come.

5) The food quality based on the cake's portion has a negative correlation -0.033 towards the visitors' motivation to buy the cake because of their curiosity to try. It means thart if the food quality based on the cake's portion increases, the visitors' motivation to buy the cake because of curiosity may decrease and vice versa. The visitors' motivation to buy the cake is not caused by their curiosity to try but the portion of Bogor taro layer cake meets the tourists' need.

\section{Shape}

1) The food quality based on the cake's shape has a negative correlation $-0.207^{*}$ towards the visitors' motivation to buy the cake as a culinary souvenir from Bogor. It means that if the food quality based on the cake's shape increases, the visitors' motivation to buy the cake as a culinary souvenir from Bogor may decrease and vice versa. The visitors' motivation to buy the cake is not cause of its status as a culinary souvenir from Bogor but the square shape of the cake. The shape shows the layers that attract tourists to buy and eat it. 
2) The food quality based on the cake's shape has a sufficient correlation $0.338 * *$ towards the visitors' motivation to buy Bogor taro layer cake because of its interesting design. It means that if the food quality based on the cake's shape increases, the visitors' motivation to buy it because of its design may increase as well and vice versa. The square shape of Bogor taro layer cake is designed to show the layers that attract tourists to visit and come.

3) The food quality based on the cake's shape has a sufficient correlation $0.366^{* *}$ towards the visitors' motivation to buy the cake because of its brand. It means that if the food quality based on the cake's shape increases, the visitors' motivation to buy it because of its brand may increase as well and vice versa. The square shape of Bogor taro layer cake with a brand of taro-based culinary product could motivate tourists to visit.

4) The food quality based on the cake's shape has a negative correlation -0.019 towards the visitors' motivation to buy the cake because of a promotion or discount. It means that if the food quality based on the cake's shape increases, the visitors' motivation to buy the cake because of the promotion or discount may decrease and vice versa. The visitors' motivation to buy the cake is not caused by promotion or discount but the square shape of the cake that shows its layers. Thus, it could attract tourists to buy the cake.

5) The food quality based on the cake's shape has a negative correlation -0.141 towards the visitors' motivation to buy the cake because of a curiosity to try. It means that if the food quality based on the cake's shape increases, the visitors' motivation to buy the cake because of their curiosity will decrease and vice versa. The visitors' motivation to buy the cake is not caused by their curiosity to try but the square shape of the cake. Its shape shows the cake's layers that attract tourists to buy it.

\section{E. Temperature}

1) The food quality based on the cake's temperature has a very weak correlation $0.222 *$ towards the visitors' motivation to buy the cake as a culinary souvenir from Bogor. It means that if the food quality based on the cake's temperature increases, the visitors' motivation to buy the cake as a culinary souvenir from Bogor may also increase and vice versa. Bogor taro layer cake is served in cold temperature or room temperature so that it can be enjoyed every time and it motivates tourists to buy it.

2) The food quality based on the cake's temperature has a negative correlation -0.134 towards the visitors' motivation to buy the cake because of its interesting design. It means that if the food quality based on the cake's temperature increases, the visitors' motivation to buy the cake because of its interesting design may decrease and vice versa. The visitors' motivation to buy the cake is not caused by its interesting design but its served temperature which is suitable for tourists to enjoy.

3) The food quality based on the cake's temperature has a negative correlation -0.036 towards the visitors' motivation to buy the cake because its brand. It means that if the food quality based on the cake's temperature increases, the visitors' motivation to buy the cake because of its brand may decrease and vice versa. The visitors' motivation to buy the cake is not caused by its brand but the cold temperature that is suitable for tourists to enjoy any time.

4) The food quality based on the cake's temperature has a negative correlation -0.060 towards the visitors' motivation to buy the cake because of a promotion or discount. It means that if the food quality based on the cake's temperature increases, the visitors' motivation to buy the cake because of the promotion or discount may decrease and vice versa. The visitors' motivation to buy the cake is not caused by any promotion or discount but the cake's cold temperature which is suitable for tourists to enjoy any time.

5) The food quality based on the cake's temperature has a very weak correlation 0.155 towards the visitors' motivation to buy the cake because of their curiosity to try. It means that if the food quality based on the cake's temperature increases, the visitors' motivation to buy the cake because of their curiosity to try may increase well and vice versa. The visitors' motivation to buy the cake is caused by the cold temperature which is suitable for tourists to enjoy any time.

\section{F. Texture}

1) The food quality based on the cake's texture has a sufficient correlation $0.486 * *$ towards visitors' motivation to buy Bogor taro layer cake as a culinary souvenir. It means that if the food quality based on the cake's texture inceases, the visitors' motivation to buy the cake may increase too and vice versa. The soft and moist texture of Bogor taro layer cake could motivate tourists to come and buy it.

2) The food quality based on the cake's texture has a very weak correlation 0.029 towards the visitors' motivation to buy the cake because of its interesting design. It means that if the food quality based on the cake's texture increases, the visitors' motivation to buy the cake because of its interesting design may increase too and vice versa. The texture of Bogor taro layer cake is purposely designed to be soft and moist. The texture could motivate tourists to come.

3) The food quality based on the cake's texture has a very weak correlation 0.096 towards visitors' motivation to buy the cake because of its brand. It means that if the food quality based on the cake's texture incrases, the visitors' motivation because of the cake's brand may increase too and vice versa. The brand of Bogor taro layer cake which is soft and moist could motivate tourists to come. 
4) The food quality based on the cake's texture has a negative correlation -0.071 towards visitors' motivation to buy the cake because of a promotion or discount. It means that if the food quality based on the cake's texture increases, the visitors' motivation to buy the cake because of promotion or discount may decrease and vice versa. The visitors' motivation to buy the cake is not caused by the promotion or discount but the cake's texture which is soft and moist. Its texture could attract tourists to buy the cake.

5) The food quality based in the cake's texture has a sufficient correlation $0.311 * *$ towards the viitors' motivation to buy the cake because of a curiosity to try. It means that if the food quality based on the cake's texture increases, the visitors' motivation to buy the cake because of a curiosity may increase and vice versa. The visitors' motivation to buy the cake is because of their curiosity to try. The cake's textures which are soft and moist could attract tourists to buy it.

\section{G. Aroma}

1) The food quality based on the cake's aroma has a sufficient correlation $0.458 * *$ towards the visitors' motivation to buy Bogor taro layer cake as a culinary souvenir. It means that if the food quality based on the cake's aroma increases, the visitors' motivation to buy the cake as a culinary souevenir may increase too and vice versa. The aroma of Bogor taro layer cake is good which could raise people's appetite and motivate tourists to come for it.

2) The food quality based on the cake's aroma has a very weak correlation 0.031 towards the visitors' motivation to buy Bogor taro layer cake because of its interesting design. It means that if the food quality based on the cake's aroma increases, the visitors' motivation to buy the cake because of its interesting design may increase as well and vice versa. The aroma of Bogor taro layer cake is good and it could raise people's appetite and motivate tourists to come.

3) The food quality based on the cake's aroma has a negative correlationf -0.081 towards the visitors' motivation to buy Bogor taro layer cake because of the cake's brand. It means that if the food quality based on the cake's aroma increases, the visitors' motivation to buy the cake because of its brand may decrease and vice versa. The visitors' motivation to buy the cake is not caused by its brand but its aroma that could raise tourists' appetite.

4) The food quality based on the cake's aroma has a very weak correlation 0.007 towards the visitors' motivation to buy the cake because of a promotion or discount. It means that if the food quality based on the cake's aroma increases, the visitors' motivation to buy the cake because of any promotion or discount may increase as well and vice versa. The aroma of Bogor taro layer cake is good and able to raise people's appetite and motivate tourists to buy it without any promotion or discount.
5) The food quality based on the cake's aroma has a sufficient correlation $0.421 * *$ towards the visitors' motivation to buy Bogor taro layer cake because of a curiosity to try. It means that if the food quality based on the cake's aroma increases, the visitors' motivation to buy the cake because their curiosity to try may increase too and vice versa. The visitors' motivaton to buy the cake is because of their curiosity to try. The cake's aroma is good and able to raise tourists' appetite.

\section{H. The level of doneness}

1) The food quality based on the cake's doneness has a sufficient correlation $0.478 * *$ towards the visitors' motivation to buy Bogor taro layer cake as a culinary souvenir from Bogor. It means that if the food quality based on the cake's doneness increases, the visitors' motivation to buy Bogor taro layer cake as a culinary souvenir may increase and vice versa. The level of the cake's doneness is good and it affects the cake's texture. Thus, it could motivate tourists to come and buy it.

2) The food quality based on the level of the cake's doneness has a very weak correlation 0.010 towards the visitors' motivation to come and buy the cake because of its interesting design. It means that if the food quality based on the level of the cake's doneness increases, the visitors' motivation to buy it because of its interesting design may increase too and vice versa. The level of the cake's doneness is good and it affects the cake's texture. Thus, it could motivate tourists to come.

3) The food quality based on the cake's doneness has a negative correlation -0.065 towards the visitors' motivation to buy the cake because of its brand. It means that if the food quality based on the cake's doneness increases, the visitors' motivation to buy the cake because of its brand may decrease and vice versa. The visitors' motivation to buy the cake is not caused by its brand but its doneness. It affects the cake's texture.

4) The food quality based on the cake's doneness has a negative correlation -0.116 towards the visitors' motivation to buy Bogor taro layer cake because of any promotion or discount. It means that if the food quality based on the cake's doneness increases, the visitors' motivation to buy the cake because of promotion or discount may decrease and vice versa. The visitors' motivation to buy the cake is not caused by promotion or discount but the level of the cake's doneness which affects the cake's texture.

5) The food quality based on the cake's doneness has a sufficient correlation $0.359 * *$ towards the visitors' motivation to buy Bogor taro layer cake because of a curiosity to try. It means that if the food quality based on the cake's doneness increases, the visitors' motivation to buy the cake because of their curiosity to try may increase too and vice versa. The visitors' motivation to try Bogor taro layer cake is caused by the well doneness of the cake. Thus, it could motivate tourists to buy it. 


\section{Taste}

1) The food quality based on the cake's flavor has a strong correlation $0.662 * *$ towards the visitors' motivation to buy Bogor taro layer cake as a culinary souvenir. It means that if the food quality based on the cake's aroma increases, the visitors' motivation to buy the cake as a culinary souvenir may increase too and vice versa. Its variants such as original cheese, taro brownies, full taro, green tea, durian taro and original taro cake with various toppings such as blueberry, strawberry, tiramisu, capuccino dan chocolate could motivate tourists to come and buy it.

2) The food quality based on the cake's flavor has a negative correlationf -0.009 towards the visitors' motivation to buy Bogor taro layer cake because of its interesting design. It means that if the food quality based on its flavor increases, the visitors' motivation to buy the cake because of its interesting design may decrease and vice versa. The visitors' motivation to come for the cake is not caused by its interesting design but its variants that could motivate tourists to buy.

3) The food quality based on the cake's flavor has a correlation 0.077 towards the visitors' motivation to buy Bogor taro layer cake because its brand. It means that if the food quality based on the cake's flavor increases, the visitors' motivation to buy the cake because of its brand may increase too and vice versa. Its variants could motivate tourists to come.

4) The food quality based on the cake's flavor has a negative correlation -0.066 towards the visitors' motivation to buy Bogor taro layer cake because of any promotion or discount. It means that if the food quality based on the cake;s flavor increases, the visitors' motivation to buy the cake because of any promotion or discount may decrease and vice versa. The visitors' motivation is not urged by any promotion or discount but the cake's variants that could attract tourists to buy.

The food quality based on the cake's flavor has a strong correlation $0.679 * *$ towards the visitors' motivation to buy Bogor taro layer cake because of a curiosity to try. It means that if the food quality based on the cake's flavor increases, the visitors' motivation to buy the cake because of their curiosity may increase too and vice versa. The visitors' motivation for Bogor taro layer cake is also caused by a curiosity to try the cake's variants. Finally, the cake's variants could attract tourists to buy the cake.

\section{CONCLUSION}

The conclusion of this research in identifying taro-based culinary products as culinary tourist attraction in Bogor is that taro-based culinary products could become a culinary tourist attraction in Bogor since the products meet the conditions required by the standard of food quality. There are variants of colors with purple as the specific color of the cake. Bogor taro layer cake has two layers and interesting topping which is shredded cheese. Bogor taro layer cake has a sufficient portion in the making so that the cake is soft and delicious to consume.
The shape is square so that it could show the layers of the cake that attract people to buy and eat it. Bogor taro layer cake is served in cold or room temperature so that tourists can eat it as soon as they buy it. Bogor taro layer cake has a soft and moist texture so that children, teenagers, adults and elders could eat it. This cake also has a specific aroma and is delicious. The level of doneness is good. It is delicious, soft, moist and not too sweet. Thus, this cake is suitable for a culinary souvenir from Bogor.

The conclusion of analyzing the relation between tarobased culinary products with the visitors' motivation in Bogor is seen from the result of Pearson Correlation. Each dimension of visitors' motivation has a negative correlation so that an improvement is required to increase visitors' motivation for taro-based culinary products. Based on the product's colors, the correlation is negative. The food quality based on the product's color has a negative correlation $-0.200^{*}$ towards the visitors; motivation to buy Bogor taro layer cake as a culinary souvenir. The food quality based on the product's color has a negative correlation -0.159 towards the visitors; motivation to buy Bogor taro layer cake because of a curiosity to try. Based on the product's appearance, the correlation is negative. The food quality based on the product's appearance has a negative correlation $-0.211 *$ towards the visitors' motivation to buy Bogor taro layer cake as a culinary souvenir. The food quality based on the product's appearance has a negative correlation $0.220 *$ towards the visitors' motivation to buy Bogor taro layer cake because of a curiosity to try. The food quality based on the product's portion has a negative correlation - 0.018 towards the visitors' motivation to buy Bogor taro layer cake as a culinary souvenir. The food quality based on the product's portion has a negative correlation - 0.033 towards the visitors' motivation to buy Bogor taro layer cake because of a curiosity to try. Based on the product's shape, the correlation is negative. The food quality based on the product's shape has a negative correlation -0.207 * towards the visitors' motivation to buy Bogor taro layer cake as culinary souvenir. The food quality based on the product's shape has a negative correlation -0.019 towards the visitors' motivation to buy Bogor taro layer cake because of any promotion or discount. The food quality based on the product's portion has a negative correlation - 0.033 towards the visitors' motivation to buy Bogor taro layer cake because of a curiosity to try. Based on the product's temperature, the correlation is negative. The food quality based on the product's temperature has a negative correlation -0.134 towards the visitors' motivation to buy Bogor taro layer cake because of its interesting design. The food quality based on the product's temperature has a negative correlation -0.036 towards the visitors' motivation to buy Bogor taro layer cake because of its brand. The food quality based on the cake's temperature has a negative correlation -0.060 towards the visitors' motivation to buy Bogor taro layer cake because of any promotion or discount. Based on the product's texture, the correlation is negative. The food quality based on the cake's texture has a negative correlation -0.071 towards the visitors' motivation to buy Bogor taro layer cake because of any promotion or discount. Based on the product's aroma, the correlation is negative. The food quality based on the product's aroma has a negative correlation - 0.081 towards the visitors' motivation to buy Bogor taro layer cake because of its brand. 
Based on the cake's doneness, the correlation is negative. The food quality based on the cake's doneness has a negative correlation -0.065 towards the visitors' motivation to buy Bogor taro layer cake because of its brand. The food quality based on the cake's doneness has a negative correlation -0.116 towards the visitors' motivation to buy Bogor taro layer cake because of any promotion or discount. Based on the product's taste, the correlation is negative. The food quality based on the product's taste has a negative correlation -0.009 towards the visitors' motivation to buy Bogor taro layer cake because of its interesting design. The food quality based on the cake's taste has a negative correlation -0.066 towards the visitors' motivation to buy Bogor layer cake because of a promotion or discount.

\section{REFERENCES}

Adi, N T Z. 2012. Membangun Aplikasi Layanan Pencarian Lokasi Kuliner Terdekat di Yogyakarta berbasis Android. Amikom Yogyakarta.

Arikunto, Suharsimi.2006. Prosedur Penelitian Suatu Pendekatan Praktik. Jakarta: Rineka Cipta

Arifin, Zainal. 2011. Evaluasi Pembelajaran.Bandung: PT.Remaja Rosdakarya.

Asdhiana, I M.2014. Kuliner Faktor Penentu Memilih Tujuan Wisata. Kompas .com.

Bogor Travel Guide. 2013. MD Media

Cerita dari bogor: Oleh-oleh unik Khas Bogor.2013. lapis bogor.blogspot.com.

Gunawan.A.Y. 2013. Motivasi Pengunjung Dalam Mengunjungi Capital Restaurant And Lounge Surabaya. Jurnal E-Komunikasi.

Hamdani. 2010. Sistem Pendukung Keputusan Wisata Kuliner Dengan Visualisasi Geografi. Jurnal Informasi Mulawarman.
Ismayanti, 2010. Pengantar Pariwisata. Penerbit PT. Gramedia Widiasarana Indonesia Jakarta

J Ganef Pah \& Sumaryadi, 2013. Kajian Wisata Kuliner Makanan dan Minuman Tradisional sebagai Atraksi Wisata. Inetrnasional Seminar of Gastronomic.

Mengenal Talas Bogor-Produk Lokal Berkualitas.2013. akardanumbi.blogspot.com

Lapis Bogor "Oleh-olehUnik Khas Bogor". 2012. www.koranbogor.com.

Lapis Bogor Sangkuriang.2012. WisataKuliner.com

Prihadi. C. 2014. Lapis Bogor Oleh-oleh yang patuh Anda bawa dari Bogor.blogspot.com.

Parma, I P G. 2012. Formulasi Strategi Pengembangan Masakan Lokal sebagai Produk Wisata Kuliner di Kabupaten Buleleng. Universitas Udaya Denpasar.

Ramadhanny. F. 2013. Lapis Bogor, Saingan beratnya Amanda Brownies.Travel Highlight Bogor.

Sarwono, J. 2012. Metode Riset Skripsi Pendekatan Kuantitatif menggunakan prosedur SPSS. PT. Elex Media Komputindo.

Sugiyono. 2008. Metode Penelitian kuantitatif kualitatif dan R\&D. Bandung Alfabeta

Sukmadinata, Nana Syadin. 2008. Metode Penelitian Pendidikan. Bandung: PT. Remaja Rosdakarya

Sudjana, Nana, Ahmad Rivai. 2011. Teknologi Pengajaran. Bandung: Sinar Baru Algensindo.

S.F. Margaretha \& Japarianto.E. 2012. Analisa Pengaruh Food Quality dan Brand Image Terhadap Keputusan Pembelian Roti Kecik Toko Roti Ganep's di Kota Solo. Jurnal Manajemen Pemasaran Vol.1, No.1.

Tempat Wisata Kuliner di Bogor Yang Terkenal. www.tempatwisata.co.id 